\title{
TERAJU
}

Teraju: Jurnal Syariah dan Hukum

Volume 02 Nomor 01, Maret 2020

DOI: https://doi.org/10.35961/teraju.v2i01.94

\section{Penemuan Hukum Oleh Hakim Perspektif Maqashid Syariah}

\author{
Rizki Pradana Hidayatulah \\ STAIN Sultan Abdurrahman Kepulauan Riau \\ riqki_pradana@stainkepri.ac.id
}

\begin{abstract}
Abstrak
Pasal 10 ayat (1) Undang-Undang Nomor 48 Tahun 2009 tentang Kekuasaan Kehakiman menentukan bahwa: "Pengadilan dilarang menolak untuk memeriksa, mengadili dan memutus suatu perkara yang diajukan dengan dalih hukum tidak ada atau kurang jelas, melainkan wajib untuk memeriksa dan mengadilinya". Dari pasal tersebut, dapat dipahami bahwa hakim sebagai pelaksana kekuasaan kehakiman, wajib menerima, memeriksa, dan mengadili suatu perkara hingga selanjutnya memberikan putusan.sehingga dengan demikian, wajib hukumnya bagi hakim untuk menemukan hukumnya dalam suatu perkara walaupun dalam hal ini ketentuan hukumnya tidak jelas, kurang jelas, bahkan tidak ada.Metode penemuan hukum dalam Islam dikenal dengan istilah ijtihad, ijtihad dilakukan oleh para mujtahid.Maqâshid syarî’ah dijadikan salah satu metode dalam penemuan hukum agar putusan yang dibuat oleh hakim dapat memenuhi unsur manfaat dalam putusan.Maqâshid syarî'ah adalah sesuatu yang sangat penting yang harus dipahami oleh setiap hakim. Hakim pada zaman sekarang adalah sebagai wakil Tuhan dalam menerapkan hukum-hukum-Nya, penemuan hukum yang dilakukan oleh para hakim adalah ijtihad yang dilakukan oleh para mujtahid.Hakim adalah mujtahid pada zaman sekarang yang tugasnya menggali hukum dari sumber-sumber yang ada untuk diterapkan dalam kehidupan manusia.
\end{abstract}

Kata Kunci: Penemuan Hukum, Maqashid Syariah, Ijtihad, Hakim.

\author{
Abstrac \\ Article 10 paragraph (1) of Law No. 48 year 2009 on judicial authority \\ determines that: "The court shall not refuse to examine, prosecute and \\ discontinue any matter filed in the pretext of the law is not or unclear, but
}


is obliged to examine and judge it". From the chapter, it can be understood that the judge as a judicial authority, obliged to accept, examine, and adjudicate a matter until then give a verdict. Thus, it is mandatory for the judge to find his law in a case even in this case the legal provisions are unclear, less obvious, not even there. The method of discovery of law in Islam is known as ljtihad, ljtihad done by the mujtahids. Maqâshid Syarî'ah be one of the methods in the discovery of law so that the verdict made by the judge can fulfill the element of benefit in the verdict. Maqâshid Syarî'ah is a very important thing that every judge must understand. The judge today is as the Lord's representative in applying his laws, the discovery of the law done by the judges is ijtihad by the mujtahids. The judge is a mujtahid in the present day whose task is to dig the law from existing sources to apply in human life.

Keywords: Discovery Law, Maqashid Syariah, Ijtihad, Judge.

\section{Pendahuluan}

Setiap aturan-aturan hukum yang mengatur kehidupan manusia, tidaklah bisa seluruhnya mengatur secara lengkap dan sempurna.Aturan-aturan itu adakala tidak lengkap dan tidak bisa menjelaskan suatu perkara.Meskipun demikian, aturan hukum yang ada tersebut tetap wajib untuk ditegakkan. Oleh sebab itu, jika ditemukannya suatu pelanggaran, maka seorang hakim harus tetap menegakkan aturan hukum itu.Dalam hal ini, hakim tidak boleh menolak suatu perkara meskipun dengan alasan tidak lengkap dan jelasnya suatu aturan hukum itu. ${ }^{1}$

Sebagaimana yang dijelaskan sebelumnya, tidak ada ketentuan hukum yang mengatur sangat lengkap maupun jelas dalam mengatur setiap aspek kehidupan manusia. Hal tersebut dikarenakan, suatu aturan hukum bersifat rigid dan kaku, sedangkan perkembangan kegiatan manusia selalu meningkat dari waktu ke waktu, baik jenis maupun jumlahnya, sehingga muncul ungkapan tertulis selalu ketinggalan dengan peristiwanya. $^{2}$

\footnotetext{
1 Pasal 10 ayat (1) Undang-undang Nomor 48 Tahun 2009 tentang Kekuasaan Kehakiman.

2 Bambang Setiyoso, Metode Penemuan Hukum, (Yogyakarta: UII Press, 2006), h. 74.
}

Penemuan hukum (rechtsvinding), lazimnya diartikan sebagai proses pembentukan hukum oleh hakim atau petugas-petugas hukum lainnya yang diberi tugas melaksanakan hukum terhadap peristiwa-peristiwa hukum yang kongkrit. ${ }^{3}$ Dengan demikian dalam upaya penemuan hukum ada beberapa unsur yang dapat terlibat dalam penemuan hukum ini, sebagai contohnya adalah ilmuan hukum yang prodak hukumnya disebut doktrin.

Metode penemuan hukum dalam Islam dikenal dengan istilah ijtihad, ijtihad dilakukan oleh para mujtahid. Hukum Islam yang kita warisi hingga kini merupakan hasil ijtihad para faqih yang sifatnya konstekstual. Tujuan dari ijtihad adalah untuk menggali hukum-hukum yang terkandung dalam al Qur'an dan al Hadis, hal ini sama dengan tujuan penemuan hukum yang dilakukan oleh para hakim untuk memutuskan perkara yaitu sama-sama untuk menggali hukum dari sumber hukum yang ada. Perbedaan antara ijtihad dalam Islam dan penemuan hukum oleh hakim terletak pada sumber hukum yang menjadi landasan utama

\footnotetext{
3 Jaenal Aripin, Peradilan Agama Dalam
} Bingkai Reformasi Hukum di Indonesia, (Jakarta: Kencana Prenada Media, 2008), h. 126. 
dalam memutuskan perkara atau masalah yang ada.

Maqâshid syarîah sebagai tujuan pokok ditetapkannya hukum supaya produk yang dihasilkan oleh hakim dapat diterima dan dilaksanakan dalam kehidupan bermasyarakat. Maqâshid alsyarî'ah adalah sebagai tujuan dari penetapan hukum, penetapan hukum menjadi kewenangan hakim pada saat ini dalam memutuskan suatu perkara. Dapat pula dikatakan bahwa maqâshid al-syarî'ah adalah tujuan segala ketentuan Allah yang disyari'atkan kepada umat manusia. Maqâshid al-syarîah bertujuan untuk kemaslahatan seluruh umat manusia. Kemaslahatan itu dapat terwujud apabila lima unsur pokok dapat diwujudkan dan terpelihara. Kelima unsur pokok itu adalah menjaga agama, jiwa, keturunan, akal danharta.

Penggunaan maqâshid syarî’ah dalam upaya rechtsvinding pada hakekatnya embrionya sudah tampak di beberapa putusan hakim. Sehingga dalam kacamata peneliti, peran dari sumbangsih maqâshid syarîah dalam upaya rechtsvinding oleh hakim sangat menarik untuk diteliti. Sebagai bentuk sensitifitas hakim dalam merespon perkembangan permasalahan hukum di masyarakat dan menciptakan hukum yang selaras dengan nilai-nilai keadilan, kepastian, dan kemanfaatan. Selain itu juga sebagai bentuk ijtihad hakim dalam merespon kekosongan hukum dan sebuah bentuk aktualisasi hukum Islam itu sendiri.

\section{Pembahasan}

A. Konsep Maqashid Syariah

Maqashid Syariah menurut bahasa terdiri dari gabungan kata yaitu maqasid dan syariah.Menurut arti katanya, Maqasid adalah merupakan bentuk jamak dari maqsad

${ }^{4}$ Amir Mu'allim dan Yusdani, Konfigurasi Pemikiran Hukum Islam, (Yogyakarta: UII Press, 1999), h. 92. yang berarti maksud dan tujuan akhir. Menurut Istilahnya, Auda memberi definisi sebagai upaya untuk memahami suatu makna dan tujuan dari suatu hukum. Menurut sejumlah pakar di bidang hukum Islam, Maqasid adalah sebuah pernyataan alternatif untuk masalih (kemaslahatan-kemaslahatan). ${ }^{5}$

Sedangkan kata Syariah secara bahasa merupakan sebuah jalan yang menuju sumber air.Secara lebih jelasnya, dapat kita pahami bahwa air menjadi kebutuhan utama dalam kehidupan manusia.Adapun kata Syariah menurut Istilahnya aturanaturan Allah yang mengatur hubungan anatara manusia dengan penciptanya, hubungan antara manusia dengan manusia lainnya dalam kehidupan sosial, dan hubungan antara manusia dengan ciptaan lainnya yang ada didalam alam semesta.Adapun syariah berdasar literatur hukum Islam memiliki 3 pembagian, yaitu; a) Syariah dalam artian hukum yang tidak pernah berubah sepanjang masa.b) Syariah dalam artian tidak dapat berubah sampai akhir zaman maupun dapat menyesuaikan dengan kondisi zaman, c) Syariah dalam artian Hukum yang didapatkan dari usaha istinbath hukum yang bersumber al-Quran dan Hadis, yang merupakan hasil interpretasi dan penafsiran oleh pakar hukum Islam melalui metode Qiyas dan lain sebagainya. ${ }^{6}$

Dari penjelasan dua kata tersebut, Maqasid merupakan tujuan dan maksud dari Allah dan Rasul-Nya yang terumuskan di dalam sumber

\footnotetext{
5 Jasser Auda, Maqasid Al-Shariah A Beginner's Guide, (London: The International Institute of Islamic Thought, 2008), h. 1.

${ }^{6}$ Zainuddin Ali, Hukum Islam: Pengantar Ilmu Hukum Islam di Indonesia, (Jakarta: Sinar Grafika, 2018), h. 3-4.
} 
hukum Islam.Tujuan dan maksud tersebut dapat ditelusuri dalam alQuran maupun Sunnah Rasulullah sebagai suatu alasan logis yang tak pernah lepas dari kemaslahatan/kepentingan umat manusia.Al-Syatibi berpendapat bahwa pada dasarnya hukum dan seperangkat aturan-aturan tersebut disyari'atkan oleh Allah kepada umat manusia memiliki maksud dan tujuan demi ketercapaiannya kemaslahatan umat manusia.?

Klasifikasi klasik maqasid meliputi 3 (tiga) jenjang keniscayaan: al-Daruriyyah (keniscayaan), alhajiyyah (kebutuhan) dan altahsiniyyah (kemewahan). Selanjutnya, keniscayaan yang paling utama dari manusia dibagi menjadi 5 bagian, yaitu: kelestarian nyawa (hifz al-din), kelestarian harta (hifz al-mal), kelestarian akal (hifz al-'aql), dan kelestarian keturunan (hifz al-nasl). ${ }^{8}$

1. Kebutuhan Dharuriyat, adalah kebutuhan yang menjadi kebutuhan utama agar manusia dapat bertahan hidup. Kebutuhankebutuhan dari umat manusia tersebut adalah agama, nyawa, akal, keturunan, dan harta. Jika tidak adanya kebutuhan tersebut, maka manusia tidak akan mampu bertahan hidup dan kemaslahatannya pun tidak akan mampu terwujud. Kelima hal inilah-menurut Al-Ghazali- yang merupakan satu kesatuan tak terpisahkan dari kehidupan umat manusia atau yang dimaksud juga dengan maslahat.

Dengan kata lain, maslahat itu adalah terjaganya 5 kebutuhan dasar dari manusia seperti disebutkan diatas. Terjaganya 5

TSatria Effendi, Ushul Fiqh, (Jakarta : Prenada Group, 2015), h. 237-238.

8Ibid.,h. 34. kebutuhan dasar tersebut telah diurutkan berdasarkan skala prioritasnya.Kebutuhan yang berada ditempat pertama adalah agama. Berarti, kebutuhan akan agama lebih penting dari kebutuhan kedua (jiwa), kebutuhan kedua juga lebih tinggi dari kebutuhan ketiga (akal), dan begitu pula seterusnya hingga sampai pada kebutuhan kelima.

2. Kebutuhan Hajizat merupakan sesuatu yang dibutuhkan manusia untuk menghilangkan segala halangan. Maksudnya adalah tidak terpenuhinya kebutuhan hajiyat ini tidak akan sampai pada terancamnya eksistensi kehidupan manusia. Akan tetapi, hanya akan berdampak pada keterhalangan yang dapat menimbulkan kesulitan saja. Pada prinsipnya, terpenuhinya aspek kebutuhan hajiyat adalah menghilangkan beban kesulitan dan memudahkan segala urusan umat manusia.

Penerapan terpenuhinya kebutuhan hajiyat contohnya adalah bahwa agama Islam telah menetapkan ketentuan dalam beberapa bidang yaitu ibadah, mu'malah maupun 'uqubat (pidana). Dalam bidang ibadah misalnya seorang muslim mendapatkan kesulitan dalam melaksanakan ibadahnya seperti berpuasa, maka ia boleh untuk tidak berpuasa di bulan Ramadhan dengan alasan bepergian atau sakit. Begitu juga dalam bidang mu'amalat, antara lain Islam memperbolehkan jual-beli pesanan (Istishna') dan jual -beli salam. Dimana dalam jual beli Istisna' barang yang dibeli tidak secara langsung diterima oleh pembeli, melainkan di waktu kemudian dikarenakan barang tersebut masih 
belum tersedia di lokasi transaksi tersebut dilakukan. Dalam hal ini, agama Islam tidak memberatkan dari pihak penjual maupun pembeli.Dan begitu pula dalam aspek 'uqubat, bahwa agama Islam menentukan pembayaran denda yang dikenal dengan diyat bagi seseorang yang tanpa dengan sengaja membuat hilangnya nyawa seseorang.

3. Kebutuhan Tahsiniyat merupakan kebutuhan yang berhubungan dengan tindakan mulia manusia. Kebutuhan Tahsiniyat ini adalah penunjang dari aspek-aspek seperi ibadah, adat, dan mu'amalah. Dari hal tersebut, dapat diartikan bahwa jikalau kebutuhan Tahsiniyat ini tidak terwujud, maka kehidupan manusia akan tetap aman-aman saja atau kehidupan manusia tidak menjadi terancam. Namun, apabila kebutuhan Tahsiniyat ini tidak ada, maka hanya akan menimbulkan kondisi-kondisi yang kurang harmonis yang dinilai dari pertimbangan akal sehat maupun adat kebiasaan. Sehingga dapat menyalahi pertimbangan akal sehat, kepatutan, sopan santun, maupun lain sebagainya. Contoh kecilnya ketika hendak beribadah, seorang muslim harus membersihkan diri dari najis, tertutup auratnya dengan baik, dan amalan-amalan lainnya yang menjadi penyempurna dari ibadahnya tersebut. Aspek lainnya dalam kebutuhan Tahsiniyat dalam kehidupan sehari-hari sangat banyak sekali, seperti berlaku sopan santun dalam makan dan minum atau dalam pergaulan sehari-hari, meninggalkan prilaku zalim, dan lain sebagainya dalam perspekti Hukum Islam maupun adat atau kebiasaan yang berlaku.
Berdasarkan penjelasan dari ketika kebutuhan diatas, dapat kita simpulkan bahwa kebutuhankebutuhan tersebut tidak dapat dipisahkan satu sama lain, melainkan saling terhubung. Sehingga kebutuhan-kebutuhan tersebut menjadi kebutuhan dasar yang sangat dibutuhkan dalam menjaga kepentingan-kepentingan umat manusia.

B. Metode Maqasid Syariah Dalam Penetapan Hukum

Pengetahuan tentang Maqasid Syariah seperti yang dijelaskan oleh Abd al-Wahhab Khallaf, merupakan alat bantu yang sangat penting dalam memahami al-Quran maupun Sunnah, dapat memberikan pemahaman pada solusi penyelesaian terhadap dalil-dalil yang bertentangan, dan suatu hal yang sangat penting juga dalam penetapan suatu hukum yang masih belum dijelaskan secara eksplisit didalam al-Quran maupun Sunnah. ${ }^{10}$

Dalam maqasid syariah yang bertujuan untuk mencari solusi dalam permasalahan-permasalahan seperti yang dijelaskan diatas, terdapat beberapa macam metode, yaitu; metode Istinbath seperti Qiyas, Istihsan, hingga Maslahah Mursalah. Qiyas, dalam perapan maqasid syariahnya, dapat diterapkan jika ditemukannya suatu alasan logis ('illat) dari suatu hukum.Contohnya adalah pada kasus diharamkannya meminum khamar seperti yang dijelaskan dalam al-Quran surah al-Maidah ayat 90.Berdasarkan pengkajian ulama, diharamkannya khamar adalah karena memiliki sifat yang memabukkan dan

${ }^{9}$ Alaiddin Koto, Filsafat Hukum Islam, (Jakarta : PT Raja Grafindo Persada, 2013), h. 4954. 
berdampak pada dapat rusaknya akal pikiran jika meminumnya.'Illat dari keharaman khamar tersebut adalah sifatnya yang memabukkan. Sebenarnya makanan maupun minuman yang dapat memabukkan itu sendiri masih banyak lagi. Oleh sebab itu, dari kasus ini dapat pula dikembangkan dengan metode qiyas.Bahwa setiap yang memiliki sifat dapat memabukkan hukumnya adalah haram.Atas dasar tersebut, apabila 'illat dari suatu hukum telah kita ketahui didalam al-Quran maupun Sunnah, kita dapat mencari hukum yang belum diketahui tersebut dengan metode qiyas.Maka dengan demikian, dapat kita simpulkan bahwa metode qiyas ini dapat kita lakukan hanyasaja bila ada suatu ayat maupun hadis yang secara jelas menjadi tempat untuk diqiyas-kannya (al-maqis 'alaih). ${ }^{11}$

Belakangan ini, banyak sekali permasalahan-permasalah baru yang muncul dan belum ditemukan hukumnya. Namun, apabila dalam penjelasan ayat maupun sunnah tidak pula ditemukan maqis 'alaih-nya secara jelas, akan tetapi masuk dalam tujuan syariah seperti pemeliharaan kebutuhan-kebutuhan yang telah dijelaskan sebelumnya, maka masalah tersebut tidak dicarikan hukumnya dengan qiyas melainkan dengan metode maslahah mursalah. Dalam literature Ushul Fiqih, yang masuk dalam kategori maslahah adalah apabila tidak bertentangan dengan aturan-aturan syariah.Jadi apabila ditemukan adanya pertentangan tersebut dengan syariah, maka dia bukanlah suatu maslahah. ${ }^{12}$

Metode-metode tersebut seperti yang dijelaskan diatas, yaitu Qiyas, Istihsan, dan Istislah (maslahah mursalah) disebut pula oleh para ulama Ushul Fiqih sebagai dalil-dalil pendukung yang dapat mencari solusi hukum demi terciptanya kemaslahatan umat manusia.

C. Penemuan Hukum Oleh Hakim

1. Konsep Penemuan Hukum Sebenarnya dalam praktiknya, masih banyak peristiwa yang masih belum ditemui aturan hukumnya. Ada beberapa peristiwa yang masih belum ada aturan hukumnya didalam perundangundangan. Paul Scholten menyatakan, bahwa merupakan suatu yang tidak mungkin bila orang menganggap perundangundangan telah sepenuhnya lengkap mengatur semua permasalahan dengan tuntas.

Penemuan hukum berbeda dengan penerapan hukum. Penemuan hukum dimaksudkan kepada ditemukannya aturan hukum yang baru dan dapat dilakukan, baik ditemukannya lewat penafsiran, analogi, maupun penghalusan hukum.Penegakan hukum tidak hanya dilakukan dengan logika penerapan hukum yang mengandalkan penggunaan logika, melainkan melibatkan penilaian dan memasuki ranah pemberian makna. ${ }^{13}$

Selanjutnya, apa sebenarnya penemuan hukum itu ?. Sudikno Mertokusumo memberi jawaban bahwa pada lazimnya penemuan hukum merupakan suatu proses terbentuknya hukum yang dilakukan oleh hakim maupun aparat hukum lainnya yang diberi tugas untuk

${ }^{13}$ Satjipto Raharjo, Penafsiran Hukum yang progresif dalam Anthon Freddy Susanto, 2005, Semiotika Hukum: Dari Dekonstruksi Teks Menuju Progresivitas Makna, Refika Aditama, Bandung, h. 9 - 11. 
melaksanakan dan menerapkan peraturan hukum. Masih menurut Sudikno dengan mengutip Eikema Holmes, yang mendefinisikan bahwa penemuan hukum merupakan sebuah proses untuk melakukan konkretisasi peraturan hukum yang memiliki sifat keumuman dengan mempertimbangkan peristiwa konkret tertentu. ${ }^{14}$ Definisi ini tidak pula berbeda dengan yang dikemukakan oleh Loudeo, bahwa penemuan hukum bukan hanya sekedar suatu proses logis belaka yang didapat melalui subsumpsi berdasarkan fakta pada ketentuan undang-undang, akan tetapi merupakan suatu penilaian dari fakta untuk kemudian menemukan hukumnya. ${ }^{15}$ Sedangkan, menurut J.A. Pointier, penemuan hukum merupakan suatu reaksi terhadap situasi yang didalamnya terdapat problematika yang dipaparkan orang dalam sebuah peristilahan hukum.Menurutnya pula, bahwa pada dasarnya penemuan hukum tersebut ditujukan untuk memberikan jawaban yang jelas terhadap pertanyaan-pertanyaan terkait hukum yang dimunculkan ke permukaan oleh kejadiankejadian konkret. ${ }^{16}$

Ada dua unsur penting dalam penemuan hukum.Pertama, hukum/sumber hukum dan kedua, adalah fakta.Pada awalnya, unsur hukum/sumber hukum dalam penemuan hukum adalah undangundang. Hal ini berkaitan dengan

${ }^{14}$ Sudikno Mertokusumo, penemuan Hukum Sebuah Pengantar, h. 37-38.

15John Z. Loude, Menemukan Hukum Melalui Tafsir dan Fakta, (Jakarta: Bina Aksara, 1985), h.V.

16.A. Pontier, Penemuan Hukum, Penerjemah B. Arief Sidharta, (Bandung: Jendela Mas Pustaka, 2008), h. 1. suatu postulat yang dikenal dengan istilah "Dewet is onschendbaar" (undang-undang tidak dapat diganggu gugat) yang dalam hukum Belanda tertuang secara eksplisit dalam pasal 120 Grondwet. Akan tetapi, dalam perkembangannya, tidak semua hukum ditemukan dalam undangundang. ${ }^{17}$ Oleh karena itu, unsur hukum/sumber hukum dalam penemuan hukum tidak hanya meliputi undang-undang semata, tetapi juga meliputi sumber hukum lainnya, yaitu doktrin, yurisprudensi, perjanjian, dan kebiasaan. ${ }^{18}$

2. Dasar Hukum Postif

Dalam pasal 1 UU No. 48 Tahun 2009 tentang kekuasaan kehakiman telah menentukan bahwa kekuasaan kehakiman adalah kekuasaan yang merdeka untuk menyelenggarakan peradilan guna menegakkan hukum dan keadilan berdasarkan Pancasila demi terselenggaranya Negara Hukum Republik Indonesia. "Merdeka" disini berarti bebas.Jadi kekuasaan kehakiman adalah bebas untuk menyelenggarakan peradilan.Kebebasan kekuasaan kehakiman atau kebebasan peradilan atau kebebasan hakim bersifat universal dimana-mana, baik di negara-negara Eropa Timur, di Amerika, Jepang, Indonesia dan sebagainya.Asas kebebasan peradilan ini merupakan harapan dari bangsabangsa manapun.

Pasal 10 ayat (1) UndangUndang Nomor 48 Tahun 2009 tentang Kekuasaan Kehakiman menentukan bahwa: "Pengadilan

${ }^{17}$ Ibid.,h. 18 dan 24.

${ }^{18}$ Eddy O.S.Hiariej, Asas Legalitas dan Penemuan Hukum, (Jakarta: Erlangga, 2009), h. 56. 
dilarang menolak untuk memeriksa, mengadili dan memutus suatu perkara yang diajukan dengan dalih hukum tidak ada atau kurang jelas, melainkan wajib untuk memeriksa dan mengadilinya". Dari pasal tersebut, dapat dipahami bahwa hakim sebagai pelaksana kekuasaan kehakiman, wajib menerima, memeriksa, dan mengadili suatu perkara hingga selanjutnya memberikan putusan.sehingga dengan demikian wajib hukumnya bagi hakim untuk menemukan hukumnya dalam suatu perkara walaupun dalam hal ini ketentuan hukumnya tidak jelas, kurang jelas, bahkan tidak ada.

Pasal 5 ayat (1) UndangUndang Nomor 48 Tahun 2009 tentang Kekuasaan Kehakiman menerangkan bahwa: "Hakim dan hakim konstitusi wajib menggali, mengikuti dan memahami nilainilai hukum dan rasa keadilan yang hidup dalam masyarakat". Jika dimaknai kata "menggali" tersebut, dapat diasumsikan bahwa hukumnya itu sudah ada, tetapi masih tersembunyi, maka untuk menemukannya hakim dengan segenap kemampuannya diharuskan menggali hukum yang hidup di lingkungan masyarakat tersebut, kemudian memahaminya agar putusannya itu tidak bertentangan dengan rasa keadilan di masyarakat.

Dengan demikian putusan hakim harus disertai dengan pertimbangan dan argumentasi hukum yang cukup, baik didasarkan aturan hukum tertulis maupun tidak tertulis.Menurut yurisprudensi Mahkamah Agung, putusan hakim yang tidak cukup dipertimbangkan dapat dibatalkan pada tingkat kasasi. Pentingnya hakim memperhatikan hukum tidak tertulis ini dipertegas lagi dalam ketentuan Pasal 5 ayat (1) Undang-Undang Nomor 48 Tahun 2009 tentang Kekuasaan Kehakiman yang menyebutkan bahwa hakim dalam memutus perkara juga mempertimbangkan hukum yang berdasar pada rasa keadilan di masyarakat.

3. Sumber Penemuan Hukum

Sumber utama dalam penemuan hukum yang dilakukan oleh hakim adalah peraturan perundang-undangan, hukum kebiasaan, yurisprudensi, perjanjian internasional, kemudian doktrin. Tidak mudah untuk membaca dan memahami suatu undang-undang.Hal tersebut disebabkan bukan hanya sekedar dilihat dari kata-katanya saja, melainkan harus lengkap pula dengan arti hingga tujuannya pula.Jika hukum dikatakan sebagai suatu sistem, maka cara memahami suatu pasal adalah dengan membaca pula pasal-pasal dalam suatu undang-undang yang lain. ${ }^{19}$ Jadi, suatu undang-undang yang kita pahami tidaklah boleh bertentangan dengan maksud dan makna dari undang-undang itu sendiri.

Jika ternyata dalam suatu undang-undang masih belum ada ketentuan solusi hukumnya, maka langkah selanjutnya adalah dengan mencarinya pada hukum kebiasaan, yang merupakan hukum tidak tertulis, yang untuk menemukannya harus menggali informasi yang mendalam dari tokoh-tokoh masyarakat yang dianggap mengerti. Kebiasaan

${ }^{19}$ Sudikno Mertokusumo, Penemuan Hukum Sebuah Pengantar, h. 50. 
adalah perilaku yang diulang.Suatu kebiasaan dianggap sebagai hukum apabila kebiasaan itu dianggap mengikat. Dalam hal ini perilaku tersebut harus berulang-ulang dan harus menimbulkan keyakinan umum bahwa perilaku yang diulang itu memang patut secara obyektif dilakukan. Secara jelasnya suatu kebiasaan dapat menjadi hukum kebiasaan, apabila kebiasaan itu merupakan: Perilaku yang dilakukan berulang-ulang, diberlakukan untuk waktu yang lama, dan adanya suatu sanksi apabila dilanggar Mengikat anggota masyarakat dimana kebiasaan itu berkembang.

Sumber penemuan hukum yang lainnya adalah yurisprudensi.Pengertian

yurisprudensi dapat diartikan sebagai tiap-tiap putusan hakim. Yurisprudensi dapat juga dipahami sebagai beberapa putusan-putusan yang dikumpulkan dan di susun secara sistematis dari tingkat pertama hingga tingkat kasasi.Ada juga yang mengartikan yurisprudensi sebagai pandangan atau pendapat para ahli yang dianut oleh hakim dan dituangkan dalam putusannya. Dalam lingkungan peradilan, dikenal adanya suatu yurisprudensi tetap, yang merupakan suatu kaidah dalam putusan yang kemudian diikuti secara tetap oleh hakimhakim selanjutnya menjadi bagian dari keyakinan hukum umum. ${ }^{20}$ Selanjutnya doktrin juga merupakan sumber penemuan hukum, seperti halnya pada definisi mengenai perjanjian sebagaimana terdapat dalam Pasal 1313 KUH Perdata yang terlalu

${ }^{20}$ Sudikno Mertokusumo, Penemuan Hukum Sebuah Pengantar, h. 52. umum dan tidak jelas, sehingga doktrin membantu memberi batasan tentang perjanjian tersebut.

4. Metode Penemuan Hukum Sudikno Mertokusumo secara garis besar membagi metode penemuan hukum menjadi 3 yaitu: $:^{21}$

a. Metode interpretasi atau penafsiran, merupakan metode penafsiran terhadap teks perundang-undangan yang masih belum jelas, dan bertujuan agar perundangundangan itu bisa diterapkan pada peristiwa konkret tertentu. Jadi, metode ini digunakan apabila suatu perundangundangannya ada, namun masih kurang jelas sehingga butuh ditafsirkan.

b. Metode argumentasi, merupakan metode yang digunakan jika suatu perundang-undangan tidak menjelaskan secara lengkap dan juga jika perundang-undangan tersebut tidak ada. Metode ini bisa juga disebut dengan metode penalaran hukum. Berdasarkan pendapat Kenneth J. Vandevelde ada 5 lang dalam penalaran hukum, yaitu; a) pengidentifikasian suatu sumber hukum yang bersumber dari peraturan perundangundangan dan putusan pengadilan, b) Penganalisisan suatu sumber hukum yang telah berhasil diidentifikasi yang bertujuan untuk menetapkan suatu aturan hukum, c) Pengsintesisan suatu aturan hukum itu ke dalam struktur yang koheren yang berupa

${ }^{21}$ Bambang Sutiyoso, Metode Penemuan Hukum, (Yogyakarta: UII Press, 2006), h. 80. 
dikelompokkannya seperangkat aturan-aturan khusus yang berada di bawah peraturan umum, d) Penelaahan faktafakta yang ada, e) Penerapan struktur aturan tersebut kepada fakta-fakta yang telah didapat yang menggunakan kebijakan dalam suatu aturan hukum untuk penyelasaian kasus.

c. Metode kontruksi hukum atau eksposisi, merupakan metode yang digunakan bagi suatu kasus yang tidak ditemukan aturan perundang-undangannya dengan cara menciptakan pengertian-pengertian hukum. Dalam hal ini, pengertian tersebut dapat dikatakan sebagai konstruksi hukum. Konstruksi hukum ini adalah suatu alat yang digunakan untuk membuat bangunan hukum dan dilakukan secara runtut dengan istilah yang baik. Metode ini memiliki tujuan supaya putusan hakim yang ditangani dapat memenuhi rasa keadilan dan memberikan kebermanfaatan untuk para pencari keadilan. Berdasarkan pendapat dari Rudolph von Jhering, ada 3 (tiga) unsur persyaratan dalam memenuhi suatu konstruksi hukum layak dilaksanakan, yaitu: a) Konstruksi hukum harus mampu meliputi semua bidang hukum, b) dalam melakukan konstruksi hukum tidak boleh terdapat pertentangan secara logis, c) Suatu konstruksi tersebut memuat unsur estetika dalam artian konstruksi tidak dibuatbuat dan harus memberikan suatu deskripsi yang lengkap dan luas sehingga memungkinkan penggabungan berbagai peraturan, pembuatan pengertian baru dan lain-lain. ${ }^{22}$

5. Tahapan Tugas Seorang Hakim dalam Proses Penemuan Hukum

Penemuan hukum merupakan suatu proses yang sangat runtut dari mulai hakim memeriksa hingga penjatuhan putusan. Pada dasarnya tahapan hakim dalam melaksanakan penemuan hukum didalam hukum acara, baik perdata maupun pidana, dibagi menjadi tiga tahap, yaitu tahap pendahuluan atau permulaan, tahap penentuan dan tahap pelaksanaan. ${ }^{23}$ Dalam melakukan prosesnya, seorang hakim harus melaksanakan 3 tahapan yaitu: ${ }^{24}$

a. Tahap konstitusir. Dalam tahapan awal ini jika seorang hakim akan mengonstitusir, maka ia harus memastikan suatu peristiwa atau kejadian dengan suatu pembuktian. Dalam hal ini hakim harus bepegangan pada alat bukti yang mendapat keabsahan oleh hukum. Sebagaimana dalam permasalahan pidana, hal ini dijelaskan dalam pasal 184 KUHAP, alat-alat bukti tersebut berupa keterangan saksi, keterangan ahli, surat, petunjuk, dan keterangan terdakwa. Adapun dalam perkara perdata, sebagaimana dalam pasal $164 \mathrm{HIR} /$ pasal $284 \mathrm{RBg} /$ pasal 1866 KUHPerdata, yaitu alat bukti tertulis, pembuktian dengan

${ }^{22}$ Acmad Ali, Menguak Tabir Hukum, (Bogor: Ghalia Indonesia, Cet. II, 2008), h. 153154., h. 191-192.

${ }^{23}$ Sudikno Mertokusumo, Penemuan Hukum Sebuah Pengantar, h. 101.

${ }^{24}$ Ahmad Rifa'i, Penemuan Hukum oleh Hakim, h. 52. 
saksi, persangkaan, pengakuan dan sumpah.

b. Tahap Mengkualifikasi. Tahapan ini adalah tahapan untuk menggolongkan atau mengelompokkan suatu peristiwa apakah peristiwa tersebut tergolong dalam peristiwa hukum atau bukan.

c. Tahap Mengkonstituir. Setelah suatu peraturan hukum telah dilakukan penerapan kepada kasus hukumnya, maka tahapan selanjutnya adalah tahapan diambilnya sebuah keputusan. Dalam tahapan ini seorang hakim harus memberikan hukumnya pada kasus itu dengan mempertimbangkan nilai keadilan kepada yang bersangkutan. Dalam mengadili suatu perkara, hakim diharuskan menetapkan hukumnya terhadap kasus tersebut melalui sumbersumber hukum yang ada.

D. Penemuan Hukum Oleh Hakim Perspektif Maqashid Al-Syariah

Penemuan hukum adalah suatu upaya untuk memberikan putusan atau kepastian untuk memutuskan suatu perkara. Metode penemuan hukum dapat bervariasi tergantung dari jenis perkara yang sedang dihadapi oleh para hakim. Ada perkara yang sudah ada undangundang yang mengaturnya akan tetapi undang-undang tersebut belum jelas maka perlu dilakukan metode penafsiran atau interpretasi, ada juga perkara yang sama sekali belum diatur dalam undang-undang sehingga timbul sebuah kekosongan hukum yang mengharuskan hakim melakukan sebuah metode kontruksi hukum untuk mengisi kekosongan hukum tersebut.
Metode interpretasi hukum dilakukan ketika peraturan perundang- undangannya ada tetapi tidak jelas, teks yang ada dalam undang-undang ditafsirkan agar peraturan tersebut dapat diterapkan kepada peristiwa konkrit. Menurut Sudikno Mertokusumo, interpretasi atau penafsiran merupakan salah satu metode penemuan hukum yang memberikan penjelasan gamblang tentang teks undang-undang, agar ruang lingkup kaidah dalam undangundang tersebut dapat diterapkan pada peristiwa hukum tertentu. ${ }^{25}$ Penafsiran oleh hakim merupakan penjelasan yang harus menuju pada pelaksanaan yang dapat diterima oleh masyarakat mengenai peraturan hukum terhadap peristiwa yang konkret.Tujuan akhir penjelasan dan penafsiran aturan tersebut untuk merealisasikan fungsi agar hukum positif itu berlaku.

Metode kontruksi hukum dilakukan ketika ada suatu perkara yang tidak dijumpai aturan perundang-undangannya dengan membentuk pengertian-pengertian hukum. ${ }^{26}$ Kontruksi hukum dilakukan untuk mengisi kekosongan hukum agar semua putusan yang dikeluarkan oleh hakim dapat memenuhi rasa keadilan serta memberikan kemanfaatan bagi para pencari keadilan.

Kekosongan hukum atau rechtvacum dapat terisi apabila hakim melakukan kontruksi antara sistem formal dan sistem materiil hukum.Berdasarkan ketentuan hukum positif yang mengandung persamaan, hakim membuat suatu pengertian hukum baru yang menjadi dasar

25 Ahmad Rifa'i, Penemuan Hukum oleh Hakim, h. 61

26Ibid.,h. 74. 
pembenaran dari putusan yang dijatuhkannya.

Teori tentang dua metode penemuan hukum diatas yang menjelaskan bahwa metode interpretasi dilakukan ketika peraturan yang menjadi landasan hakim dalam memutuskan perkara sudah ada akan tetapi kurang jelas atau dapat diartikan dengan banyak makna dan metode kontruksi hukum dilakukan ketika hakim tidak menemukan aturan perundangundangan untuk digunakan sebagai landasan memutuskan sebuah perkara.

Dalam islam dikenal metode ijtihad sebagai sebuah metode istimbath para ahli fiqih untuk mengeluarkan hukum syar'i dari dalildalil syara'. Menurut al- Syatibi, antara ijtihad dengan maqashid al-syariah tidak dapat dipisahkan. Ijtihad pada intinya adalah upaya penggalian hukum syara' secara optimal.Upaya penggalian hukum syara' itu berhasil apabila seorang mujtahid dapat memahami maqâshid al-syarî’ah.Oleh karenanya pengetahuan tentang maqâshid al-syarî’ah adalah salah satu syarat yang dimiliki oleh seorang mujtahid. $^{27}$

Kedudukan maqâshid alsyarî'ah dalam metode penemuan hukum adalah sebagai landasan atau dasar pertimbangan yang digunakan hakim dalam memutuskan suatu perkara ketika hakim sudah tidak menemukan sumber hukum pasti atau sumber hukum yuridis yang dapat digunakan sebagai landasan seorang hakim untuk memutuskan suatu perkara, baik itu di dalam Undang- undang, PP atau yurisprudensi.Dijelaskan pula bahwa

27 Asafri Jaya Bakri, Konsep Maqashid Syari'ah menurut al- Syatibi, (Jakarta: P.T. Raja Grafindo Persada, 1996), h. 129. tujuan dari putusan yang dibuat oleh hakim adalah memberikan keadilan substantif yang berupa kemanfaatan bagi masyarakat atau para pihak yang sedang berperkara, karena kemanfaatan itulah yang diinginkan oleh pihak yang berperkara ketika mengajukan masalah yang dihadapinya ke Pengadilan.

Seorang hakim harus mengutamakan sumber-sumber hukum tertulis seperti Undangundang, Peraturan pemerintah dan yurisprudensi. Pada dasarnya semua peraturan yang dibuat oleh manusia tidak dapat mengatur seluruh kegiatan manusia, sehingga ada kalanya perkara yang diajukan ke Pengadilan tidak ditemukan dasar hukumnya, akan tetapi hakim tidak bisa menolak sebuah perkara dengan alasan peraturannya belum ada atau tidak ada Undang-undang yang mengaturnya.Pasal 10 ayat (1) Undang-Undang Nomor 48 Tahun 2009 tentang Kekuasaan Kehakiman menentukan bahwa: "Pengadilan dilarang menolak untuk memeriksa, mengadili dan memutus suatu perkara yang diajukan dengan dalib bukum tidak ada atau kurang jelas, melainkan wajib untuk memeriksa dan mengadilinya". ${ }^{28}$

Hakim dalam memeriksa, mengadili, dan memutuskan suatu perkara yang dihadapkan kepadanya, pertama-tama harus menggunakan hukum tertulis terlebih dahulu, yaitu peraturan perundang-undangan, tetapi kalau peraturan perundangundangan itu tidak cukup atau tidak tepat dengan permasalahan dalam suatu perkara, maka barulah hakim akan mencari dan menemukan sendiri hukumnya dari sumber- sumber hukum yang lain, seperti

${ }^{28}$ Undang-Undang Republik Indonesia Nomor 48 Tahun 2009 tentang Kekuasaan Kehakiman. PDF. 
yurisprudensi, doktrin, traktat, kebiasaan atau hukum tidak tertulis. ${ }^{29}$ Dengan begitu hakim bisa juga menggunakan maqâshid alsyarî'ah sebagai landasan pertimbangan ketika tidak ada hukum yang pasti yang mengatur suatu perkara karena hakim memiliki kebebasan menggunakan keilmuannya dalam memutuskan perkara yang dihadapinya.

Melihat dari pengertian maqâshid al-syarî'ah, yaitu tujuan Allah swt sebagai syari' (pembuat hukum) dalam menetapkan hukum terhadap hamba-Nya. ${ }^{30}$ Menurut alSyatibi maqâshid al-syarî'ah dan metode penggalian hukum yang di dalam islam disebut dengan ijtihad tidak dapat dipisahkan, seorang mujtahid dikatakan berhasil melakukan ijtihad bila mujtahid memahami maqâshid al-syarî̀ah. ${ }^{31}$ Pengetahuan tentang maqâshid alsyarî’ah, seperti ditegaskan oleh Abdul al-Wahhab Khallaf, adalah hal yang sangat penting yang dapat dijadikan alat bantu untuk memahami redaksi al Qur'an dan al Sunnah, menyelesaikan dalil-dalil yang bertentangan dan yang sangat penting lagi adalah untuk menetapkan hukum terhadap kasus yang tidak tertampung oleh al Qur'an dan Sunnah secara kajian kebahasaan. ${ }^{32}$

29 Ahmad Rifa'i, Penemuan Hukum oleh Hakim, h. 6. Lihat Juga Abdillah, Kudrat, Maylissabet, M. Taufiq, Kontribusi Bahtsul Masail Pesantren di Madura dalam Menghadapi Perkembangan Hukum Islam Kontemporer, Jurnal Perada: Jurnal Studi Islam Kawasan Melayu, 2019.

${ }^{30}$ Amir mu'allim dan Yusdani, Konfigurasi Pemikiran Hukum Islam, (Yogyakarta: UII Press, 1999), h. 92.

31 Asafri Jaya Bakri, Konsep Maqashid Syariah menurut al- Syatibi, (Jakarta: P.T. Raja grafindo Persada, 1996), h. 129.

32 Satria Effendi, Ushul Figh, (Jakarta: Prenada Media, 2005), h. 237.
Sudah menjadi tugasnya melaksanakan hukum-hukum Allah, maksudnya Islamlah yang menjadi dasar hakim dalam melaksanakan tugasnya, dalam membuat putusan untuk memutuskan sebuah perkara hakim tentunya menggunakan maqâshid al-syarî̀ah sebagai dasarnya, yang dimaksud maqâshid al-syarîah adalah menjaga agama, menjaga akal, menjaga jiwa, menjaga keturunan dan menjaga harta.

Selain menggunakan metode interpretasi hukum dan kontruksi hukum yang digunakan hakim dalam penemuan hukum, hakim juga menggunakan maqâshid al-syarîah sebagai metodenya.Kedudukan maqâshid al-syarî̀ah dalam penemuan hukum sendiri sangatlah penting, karena berkaitan dengan kemanfaatan hukum.Kemanfaatan hukum adalah salah satu dari tiga tujuan hukum yaitu keadilan, kemanfaatan dan kepastian hukum.Putusan yang dibuat oleh hakim bagaimanapun juga harus bisa memberikan manfaat kepada para pihak, jadi bukan hanya keadilan dan kepastian hukum yang dijadikan orientasi hakim tapi juga kemanfaatan.

Pendapat hakim terhadap kedudukan maqâshid al-syarî'ah dalam penemuan hukum ada dua macam, pendapat pertama menyatakan bahwa maqâshid alsyarîah yang berjumlah 5, yaitu menjaga agama, menjaga akal, menjaga jiwa, menjaga keturunan dan menjaga harta, itu digunakan hakim sebagai landasan pertimbangan dalam membuat putusan ketika dalam sumber hukum yuridis atau sumber hukum yang pasti tidak ditemukan aturan yang mengatur sebuah perkara yang dihadapi oleh hakim.

Maqâshid al-syarî’ah digunakan hakim sebagai metode 
dalam memutuskan perkara. Bahwa maqâshid al-syarî'ah sama halnya dengan metode teleologis/sosiologis, yaitu metode yang memandang tujuan hukum yang tercantum dalam teks sebagai acuan utama hakim dalam memberikan putusan. Pendapat lain mengatakan bahwa maqâshid alsyarî̀ah dijadikan salah satu metode dalam penemuan hukum agar putusan yang dibuat oleh hakim dapat memenuhi unsur manfaat dalam putusan.

Menurut hemat penulis maqâshid al-syarî'ah adalah sesuatu yang sangat penting yang harus dipahami oleh setiap hakim.Hakim pada zaman sekarang adalah sebagai wakil Tuhan dalam menerapkan hukum-hukum-Nya, penemuan hukum yang dilakukan oleh para hakim adalah ijtihad yang dilakukan oleh para mujtahid.Hakim adalah mujtahid pada zaman sekarang yang tugasnya menggali hukum dari sumber-sumber yang ada untuk diterapkan dalam kehidupan manusia. Sebagaimana yang dijelaskan oleh al Syatibi dan Wahbah Zuhaili bahwa maqâshid al-syarî’ah sangat penting untuk dipahami oleh setiap mujtahid untuk digunakan sebagai alat bantu memahami sumber hukum utama yaitu al Qur'an dan al Hadits, menyelesaikan dalil-dalil yang bertentangan dan yang sangat penting lagi adalah untuk menetapkan hukum terhadap kasus yang tidak tertampung oleh al Qur'an dan Sunnah secara kajian kebahasaan. ${ }^{33}$ Seorang mujtahid dikatakan berhasil jika dia memahami maqâshid al-syarî’ah dalam ijtihadnya.Al Qur'an dan al Hadits sebagai sumber utama melakukan ijtihad bisa dianalogikan sebagai sumber hukum dalam metode penemuan hukum yang dilakukan hakim, maka hakim juga bisa dikatakan berhasil melakukan penemuan hukum untuk menyelesaikan perkara jika hakim memahami tujuan-tujuan dibentuknya hukum tersebut.

\section{Kesimpulan}

Dari pembahasan diatas, dapat disimpulkan bahwa metode penemuan hukum yang dilakukan oleh hakim dapat melalui 3 metode, yaitu: a) Metode interpretasi atau penafsiran, merupakan metode penafsiran terhadap teks perundang-undangan yang masih belum jelas, dan bertujuan agar perundangundangan itu bisa diterapkan pada peristiwa konkret tertentu, b) Metode argumentasi, merupakan metode yang digunakan jika suatu perundang-undangan tidak menjelaskan secara lengkap dan juga jika perundang-undangan tersebut tidak ada, dan c)Metode kontruksi hukum atau eksposisi, merupakan metode yang digunakan bagi suatu kasus yang tidak ditemukan aturan perundangundangannya dengan cara menciptakan pengertian-pengertian hukum. Dalam hal ini, pengertian tersebut dapat dikatakan sebagai konstruksi hukum.Konstruksi hukum ini adalah suatu alat yang digunakan untuk membuat bangunan hukum dan dilakukan secara runtut dengan istilah yang baik.Metode ini memiliki tujuan supaya putusan hakim yang ditangani dapat memenuhi rasa keadilan dan memberikan kebermanfaatan untuk para pencari keadilan.

Dalam islam dikenal metode ijtihad sebagai sebuah metode istimbath para ahli fiqih untuk mengeluarkan hukum syar'i dari dalil-dalil syara'. Menurut al- Syatibi, antara ijtihad dengan maqashid al-syariah tidak dapat dipisahkan. Ijtihad pada intinya adalah upaya penggalian hukum syara' secara optimal.Upaya penggalian hukum syara' itu berhasil apabila seorang mujtahid dapat memahami maqâshid al-

${ }^{33}$ Satria Effendi, Ushul Fiqh, h. 237. 
syarî’ah.Oleh karenanya pengetahuan tentang maqâshid al-syarî'ah adalah salah satu syarat yang dimiliki oleh seorang mujtahid.

Kedudukan maqâshid al-syarî'ah dalam upaya penemuan hukum yang dilakukan oleh hakim adalah sebagai landasan pertimbangan ketika tidak ada aturan yang mengatur suatu perkara untuk dijadikan landasan. Maqâshid al-syarî’ah merupakan suatu metode yang digunakan untuk memahami tujuan dibentuknya peraturan perundang-undangan, selain itu penggunaan maqâshid al-syarîah dalam penemuan hukum agar supaya putusan yang dibuat hakim dapat bermanfaat bagi para pihak. Menurut para ulama memang antara ijtihad dan maqâshid al- syarî̀ah tidak bisa dipisahkan, karena maqâshid syarî'ah adalah alat untuk memahami al Qur'an dan al Hadits sebagai sumber utama hukumislam.Penemuan hukum yang dilakukan hakim intinya sama dengan ijtihad yang dilakukan para ahli fiqih, sehingga dalam penemuan hukum juga harus ada unsur maqâshid al-syarî'ah

\section{Daftar Pustaka}

Abdillah, Kudrat, Maylissabet, M. Taufiq, Kontribusi Babtsul Masail Pesantren di Madura dalam Menghadapi Perkembangan Hukum Islam Kontemporer, Jurnal Perada: Jurnal Studi Islam Kawasan Melayu, 2019.

Ali, Acmad, Menguak Tabir Hukum, (Bogor: Ghalia Indonesia, Cet. II, 2008)

Ali, Zainuddin,Hukum Islam: Pengantar Ilmu Hukum Islam di Indonesia, (Jakarta: Sinar Grafika, 2018)

Aripin, Jaenal,Peradilan Agama Dalam Bingkai Reformasi Hukum di Indonesia, (Jakarta: Kencana Prenada Media, 2008)

Auda, Jasser,Maqasid Al-Shariah A Beginner's Guide, (London: The International Institute of Islamic Thought, 2008)

Effendi, Satria, Ushul Figh, (Jakarta: Prenada Media, 2005)

Jaya Bakri, Asafri,Konsep Maqashid Syariah menurut al- Syatibi, (Jakarta: P.T. Raja grafindo Persada, 1996)
Koto, Alaiddin,Filsafat Hukum Islam, (Jakarta : PT Raja Grafindo Persada, 2013)

Loude, John Z.,Menemukan Hukum Melalui Tafsir dan Fakta, (Jakarta: Bina Aksara, 1985)

Mu'allim, Amir dan Yusdani, Konfigurasi Pemikiran Hukum Islam, (Yogyakarta: UII Press, 1999)

O.S.Hiariej, Eddy,Asas Legalitas dan Penemuan Hukum, (Jakarta: Erlangga, 2009)

Pontier, J.A., Penemuan Hukum, penerjemah B. Arief Sidharta, (Bandung: Jendela Mas Pustaka, 2008)

Rifai,Ahmad,Penemuan Hukum Oleh Hakim Dalam Perspektif Hukum Progresif, (Jakarta: Sinar Grafika, Cet I, 2010)

Setiyoso, Bambang,Metode Penemuan Hukum, (Yogyakarta: UII Press, 2006) 